\title{
ZARZĄDZANIE EKSPLOATACJĄ OBIEKTU W UJĘCIU KOSZTÓW CYKLU ŻYCIA
}

\author{
Beata Grzyl ${ }^{\bowtie}$, Magdalena Apollo, Emilia Miszewska-Urbańska, Adam Kristowski \\ Wydział Inżynierii Lądowej i Środowiska, Politechnika Gdańska, Gdańsk
}

\begin{abstract}
STRESZCZENIE
W artykule przedstawiono wstępne informacje, niezbędne do ustalenia zakresu i kierunku opracowania koncepcji metody optymalizacji kosztów cyklu życia wybranych obiektów budowlanych. Zwrócono uwagę na ścisłe powiązanie pomiędzy decyzjami podejmowanymi na etapie projektowania a wydatkami ponoszonymi w toku utrzymania i użytkowania obiektów, zaprezentowano specyfikę kosztów cyklu życia i składowe tych kosztów oraz przykład zastosowania analizy LCC w tym zakresie.
\end{abstract}

Słowa kluczowe: koszt cyklu życia - LCC, eksploatacja, obiekt budowlany

\section{WSTĘP}

Jednym z zasadniczych priorytetów UE realizowanych w ramach strategii Europa 2020 jest zrównoważony rozwój polegający m.in. na wspieraniu gospodarki efektywnie korzystającej z zasobów, przyjaznej środowisku i konkurencyjnej. W wielu dokumentach UE propagujących zrównoważony rozwój jako podstawę podejmowania decyzji jest wskazywana metoda szacowania kosztów cyklu życia (LCC - Life Cycle Cost, np. PN-EN 60300-3-3:2006. Zarządzenie niezawodnością. Część 3-3: Przewodnik zastosowań. Szacowanie kosztu cyklu życia). Polega ona na obliczaniu całkowitego kosztu produktu, wyrobu, usługi lub obiektu, generowanego w okresie od pozyskania surowców po zagospodarowanie odpadów, przy uwzględnieniu fazy projektowania, instalacji (montażu, wybudowania), eksploatacji, konserwacji, recyklingu lub utylizacji (Dyrektywa Parlamentu Europejskiego i Rady, 2009).

Zgodnie z ideą zrównoważonego rozwoju na etapie projektowania obiektu budowlanego należy wykorzystać analizę LCC w celu zoptymalizowania kosztów jego cyklu życia, z uwzględnieniem bezpieczeństwa użytkowania, stopnia funkcjonalności, awaryjności, częstości dokonywania zabiegów konserwacyjnych itp. Około 80-90\% kosztów ponoszonych w toku realizacji, użytkowania i eksploatacji obiektu zostaje określonych na etapie projektowania. W praktyce $\mathrm{w}$ wielu przypadkach koszty ponoszone w pełnym cyklu życia są jednak pomijane, a decyzje inwestycyjne są podejmowane na podstawie kryteriów krótkoterminowych. Działania takie powodują negatywne następstwa nie tylko o charakterze finansowym, ale i środowiskowym (np. pojawia się konieczność wcześniejszej utylizacji powstałego odpadu). Z uwagi na fakt, iż żywotność niektórych obiektów sięga 50-70 lat, koszty związane z ich użytkowaniem i utrzymaniem zdecydowanie przewyższają nakład początkowy (Grzyl i Kristowski, 2014).

${ }^{\bowtie}$ bena@pg.gda.pl 
Do czynników mających decydujący wpływ na koszt cyklu życia obiektu budowlanego należą przede wszystkim: rodzaj i charakter podejmowanych działań związanych z utrzymaniem i użytkowaniem (Jankowski, Migda i Szczepański, 2016), warunki pogodowe (czynniki klimatyczne), lokalizacja i poziom funkcjonalności. Zasadniczym wydatkiem w cyklu życia obiektu budowlanego są koszty ponoszone przez zarządców i właścicieli obiektów, związane z ich utrzymaniem i użytkowaniem.

W toku prowadzonych przez autorów poszukiwań rozwiązań optymalizacyjnych, odnoszących się do zarządzania eksploatacją obiektów budowlanych, przeprowadzona zostanie identyfikacja i analiza zasadniczych czynników generujących znaczne koszty, a mogących ulec istotnemu ograniczeniu (na etapie użytkowania i utrzymania). W zależności od zakresu uzyskanych danych wejściowych (np. w postaci danych historycznych) w analizie LCC zostanie uwzględniony średni zakres, koszt oraz czas remontu obiektu, a także koszty użytkowników obiektu.

\section{STRUKTURA KOSZTÓW CYKLU ŻYCIA OBIEKTU}

W aspekcie kosztów generowanych w kolejnych fazach cyklu życia obiektu budowlanego wyróżnia się (Plebankiewicz, Biadała i Wieczorek, 2015):

- koncepcję i definiowanie (m.in. koszty badania rynku, analiz koncepcji, definiowania wymagań stawianych produktowi),

- projektowanie i rozwój (m.in. koszty opracowania dokumentacji projektowej, produkcji prototypu, oprogramowania, zarządzania jakościa),

- produkcję (m.in. koszty produkcji, dostarczenia na rynek - pakowania, załadunku, transportu),

- instalację, montaż, wybudowanie,

- użytkowanie i obsługiwanie (koszty remontów, konserwacji, części zamiennych, wsparcia technicznego, ponoszone w założonym czasie eksploatacji urządzenia, obiektu),

- likwidację (m.in. koszty demontażu, recyklingu lub utylizacji).

Łączne koszty ponoszone w cyklu życia obiektu można także podzielić na koszty nabycia i posiadania (Dyrektywa Parlamentu Europejskiego i Rady, 2009). Koszty nabycia obejmują przede wszystkim koszty inwestycyjne - budowy obiektu (tj. projektowania i wytworzenia). Koszty posiadania to m.in. koszty obsługi, konserwacji, planowanych remontów, usuwania awarii, ale także koszty środowiskowe, społeczne i wycofania z eksploatacji. Zazwyczaj koszty posiadania przewyższają koszty nabycia.

\section{METODY ANALIZY LCC I ICH OGRANICZENIA}

W procesie przeprowadzania analizy LCC można wyróżnić kilka kluczowych etapów. Ważnym elementem szacowania kosztów cyklu życia obiektu jest zdefiniowanie działań, które mają wpływ na obniżenie lub wzrost kosztów oraz ustalenie korelacji pomiędzy nimi (Plebankiewicz, 2014). Istotnym aspektem analizy są dane kosztowe pozyskane od zarządców i właścicieli nieruchomości (gdy informacje takie są gromadzone). Znaczącym elementem analizy LCC jest także ustalenie okresu życia danego obiektu (np. 50-70 lat) oraz wysokość stopy dyskontowej. Sformułowane w ten sposób dane wejściowe można przetworzyć, wykorzystując określony model obliczeniowy (Plebankiewicz, Zima i Wieczorek, 2016).

Wyróżnia się dwie zasadnicze grupy metod prowadzenia analizy LCC (PN-EN 60300-3-3: 2006):

- prostą, służącą nieskomplikowanym porównaniom, pozwalającą na wybór optymalnego wariantu z pominięciem procesu dyskontowania,

- złożoną, obejmującą analizę zdyskontowanych przepływów pieniężnych w okresie do wycofania obiektu z użytkowania, integrującą różne elementy kosztów ponoszonych w cyklu życia (np. utrzymanie, użytkowanie, naprawy, przeglądy, demontaż). 
Wybór odpowiedniej metody obliczania LCC zależy od charakteru, zakresu i stopnia złożoności przedsięwzięcia. Jedną z propozycji stanowi metoda opisana przez Siemaszko i Kembłowskiego (2016).

Do metod, które mogą być wykorzystane do oszacowania składowych kosztu cyklu życia obiektu, należą (PN-EN 60300-3-3:2006):

- inżynierska metoda szacowania kosztu (bezpośrednie badanie wyrobu, komponent po komponencie),

- metoda szacowania kosztu przez analogię (oszacowanie oparte na nabytym doświadczeniu z podobnymi wyrobami lub technologiami),

- parametryczna metoda szacowania kosztu (wykorzystanie parametrów i zmiennych w celu opracowania zależności oszacowania kosztu).

Analiza LCC stanowi nowe podejście wykorzystywane coraz szerzej m.in. w procesie projektowania i podejmowania decyzji inwestycyjnej dotyczącej wyboru obiektu o określonych parametrach. W praktyce napotyka jednak na trudności i ograniczenia charakterystyczne dla wielu technik i narzędzi kosztowych. Najpoważniejsze $\mathrm{z}$ nich zaprezentowano poniżej:

1. Analiza LCC nie jest metodą ścisłą, w efekcie czego może generować różne rezultaty. Wynika to m.in. $\mathrm{z}$ faktu, iż koszty uwzględnione $\mathrm{w}$ analizie są jedynie wartościami przybliżonymi (przede wszystkim te przypisane do fazy eksploatacji, utrzymania i likwidacji), dodatkowo wymagana jest duża liczba danych wejściowych (np. trudnych do pozyskania od zarządców lub właścicieli obiektów).

2. W praktyce obserwuje się brak szerokiej wiedzy projektantów na temat technologii prowadzenia prac remontowych obiektów i związanych z tym kosztów. Dodatkowo istnieje duża trudność w oszacowaniu na etapie projektowania kosztów społecznych, administracyjnych, gospodarczych i środowiskowych.

3. Brak wiarygodnych danych dotyczących utrzymania i użytkowania obiektów wynika z faktu, iż większość zarządców/właścicieli nie posiada odpowiedniej metody służącej do systematycznego zbierania i gromadzenia danych.

\section{PRZYKŁADY ANALIZY LCC}

Autorzy artykułu prezentują przykładową kalkulację wybranych elementów kosztu cyklu życia obiektu - budynku użyteczności publicznej, zrealizowanego w technologii standardowej oraz energooszczędnej. W analizie nie uwzględniono wydatków związanych z prowadzeniem działań remontowych, utrzymaniowych, konserwacyjnych, usuwaniem awarii itp. oraz rozbiórki obiektu i utylizacji materiałów. W celu przeprowadzenia obliczeń wykorzystano dane i informacje zawarte w innej pracy (Węglarz, Pierzchalski i Koc, 2016). Do kalkulacji kosztów przyjęto następujące założenia: okres użytkowania obiektu - 30 lat, stawka za energię elektryczną - średnia netto dla regionu pomorskiego, zastosowanie prostej metody prowadzenia analizy LCC (z pominięciem procesu dyskontowania).

Zwrócono uwagę, iż rachunek kosztów cyklu życia obiektu budowlanego stanowi podstawę podejmowania długoterminowych decyzji inwestycyjnych, ale ma także istotny wpływ na podniesienie ich efektywności środowiskowej (mniejsze zużycie energii, niższa emisja $\mathrm{CO}_{2}$ ). Zwiększenie początkowych nakładów kapitałowych zazwyczaj skutkuje obniżeniem bieżących kosztów w cyklu życia oraz zwiększeniem wartości końcowej nieruchomości.

Wyniki przedstawione w tabeli 1 wskazują, iż uwzględniając wartość nakładu początkowego oraz dodatkowe korzyści, np. w postaci redukcji emisji $\mathrm{CO}_{2}$, można stwierdzić, że korzystniejsza dla zamawiającego jest realizacja budynku w technologii energooszczędnej. Koszty zużycia energii w toku użytkowania obiektu stanowią znaczną część całkowitych kosztów jego posiadania. Zmniejszenie zużycia energii jest efektywnym rozwiązaniem zarówno pod względem finansowym, jak i środowiskowym. Ważna jest również oszczędność w zakresie konserwacji urządzeń i wymiany wyposażenia. Warte rozważenia jest rozwiązanie, które przewiduje wydłużony okresu ich wymiany, a także dobór takich materiałów, które ograniczą częstotliwość 
Tabela 1. Analiza porównawcza kosztu (nakładu początkowego) i innych parametrów dla budynku użyteczności publicznej, realizowanego w Polsce w technologii standardowej i energooszczędnej (opracowanie własne na podstawie Węglarz i in., 2016)

Table 1. Comparative analysis of cost and other parameters for a public building, carried out in Poland in the standard and energy-efficient technology (authors' own elaboration based on Węglarz et al., 2016)

\begin{tabular}{lcc}
\hline Opis & Budynek (referencyjny) & $\begin{array}{c}\text { Budynek w technologii } \\
\text { energooszczędnej }\end{array}$ \\
Description & w technologii standardowej & Building in energy efficient \\
& Building in the standard technology & \begin{tabular}{c} 
techy \\
\hline
\end{tabular}
\end{tabular}

Zapotrzebowanie na energię elektryczną $\left[\mathrm{kWh} \cdot \mathrm{rok}^{-1}\right]$ Electricity demand $\left[\mathrm{kWh} \cdot \mathrm{year}^{-1}\right]$

69474,00

45331,00

Łączny koszt energii elektrycznej w okresie 30 lat

$\left(0,2372\right.$ PLN netto $\left.\mathrm{kWh}^{-1}\right)$

Cost of electricity over 30 years

$\left(0.2372 \mathrm{PLN}\right.$ netto $\left.\cdot \mathrm{kWh}^{-1}\right)$ 494 376,98 PLN (30 lat/30 years) 322575,40 PLN (30 lat/30 years)

Zapotrzebowanie na energię cieplną [GJ $\cdot \mathrm{rok}^{-1}$ ]

Heat energy demand [GJ·year ${ }^{-1}$ ]

[PLN $\cdot$ rok $\left.^{-1}\right]$

Cost of heating and hot water (without lighting)

[PLN·year ${ }^{-1}$ ]

Łączny koszt ogrzewania i ciepłej wody

(bez oświetlenia) w okresie 30 lat [PLN]

Cost of heating and hot water (without lighting)

over 30 years [PLN]

Koszt inwestycji (nakład początkowy) [PLN]

Initial cost of investment [PLN]

Łączny koszt energii elektrycznej, ogrzewania

i ciepłej wody w okresie 30 lat [PLN]

The total cost of electricity, heating and hot water

over a period of 30 years [PLN]

Różnica w kosztach (nakładach początkowych)

inwestycji [PLN]

Difference in investment costs [PLN]

Redukcja emisji $\mathrm{CO}_{2} \mathrm{w}$ okresie 30 lat $\left[\mathrm{Mg} \cdot \mathrm{rok}^{-1}\right]$

$\mathrm{CO}_{2}$ emissions reduction over 30 years $\left[\mathrm{Mg} \cdot\right.$ year $\left.^{-1}\right]$
2719,00

210808,50

184,00

43002,00

$6324255,00 \quad 1290060,00$

$42450000,00 \quad 44560000,00$

$6818631,98 \quad 1612635,40$

2460000,00

9262

prowadzenia działań konserwacyjnych, naprawczych i remontowych. Istotną kwestią są także koszty likwidacji obiektu, obejmujące zarówno koszt usunięcia, jak i bezpiecznej utylizacji niektórych materiałów.

\section{PODSUMOWANIE}

Przeprowadzone w artykule rozważania uzasadniają sformułowanie niżej podanych wniosków, stwierdzeń i zaleceń:

1. Wykorzystanie analizy LCC na etapie koncepcji, definiowania i projektowania obiektu daje duże możliwości redukcji kosztów w cyklu jego życia. Z uwagi na brak wielu informacji, dotyczących kosztów eksploatacji 
i likwidacji danego typu obiektu, dalsze badania prowadzone przez autorów w tym zakresie będą obejmowały m.in. utworzenie bazy danych na temat kosztów utrzymania obiektów na podstawie informacji uzyskanych od zarządców i właścicieli obiektów budowlanych.

2. Jak wskazuje praktyka, jedną z przyczyn zwiększenia kosztów eksploatacyjnych obiektów jest stosowanie przez zarządców i właścicieli obiektów nieadekwatnych i przestarzałych technologii napraw i remontów - błędnie dobrana technologia przyczynia się do zwiększenia kosztów dalszych napraw i remontów.

3. Pomimo licznych ograniczeń (m.in. ustalenia poszczególnych składowych kosztów) analiza LCC może być stosowana do oceny efektywności wariantów budowy lub nabycia nowych obiektów, a także modernizacji istniejących. Dostarcza ona przejrzystej informacji o możliwych konsekwencjach rozpatrywanych rozwiązań, z uwzględnieniem m.in. kosztu, okresu trwałości i parametru niezawodności obiektu.

\section{PIŚMIENNICTWO}

Dyrektywa Parlamentu Europejskiego i Rady 2009/125/WE z dnia 21 października 2009 r. ustanawiająca ogólne zasady ustalania wymogów dotyczących ekoprojektu dla produktów związanych z energią.

Grzyl, B. i Kristowski, A. (2014). A calculation proposal of labour time input when concreting in difficult atmospheric conditions. Czasopismo Techniczne, Budownictwo, Zeszyt 2-B (6).

Jankowski, R., Migda, W. i Szczepański, M. (2016). Timber-frame house resistant to dynamic loads - analysis of wall panel filled with polyurethane foam. Vibrations in Physical Systems, 27, 347-354.

Plebankiewicz, E. (2014). Kierunki działań zmierzających do obniżenia kosztów w cyklu życia budynków miejskich. W A. Halicka (red.), Budownictwo na obszarach zurbanizowanych: Nauka, praktyka, perspektywy. Lublin: Politechnika Lubelska.

Plebankiewicz, E., Biadała, K. i Wieczorek, D. (2015). Life cycle costs of built structures. In E. Plebankiewicz (red.), Recent advances in Civil Engineering: Construction Management. (strony 83-96). Kraków: Wydawnictwo Politechniki Krakowskiej.

Plebankiewicz, E., Zima, K. i Wieczorek, D. (2016). Life cycle cost modelling of buildings with consideration of the risk. Archives of Civil Engineering, 62(2), 149-166. doi: 10.1515/ace-2015-0071.

PN-EN 60300-3-3:2006. Zarządzanie niezawodnością. Część 3-3: Przewodnik zastosowań. Szacowanie kosztu cyklu życia.

Siemaszko, A. i Kembłowski, M. W. (2016). Ocena efektywności monitoringu obiektów inżynierskich za pomocą sieci Bayesa. Materiały Budowlane, 6, 137-138.

Węglarz, A., Pierzchalski, M. i Koc, D. (2016). Koszty w cyklu życia budynku. W Cena lub koszt cyklu życia. Nowe uwarunkowania $w$ zamówieniach publicznych na roboty budowlane. Materiały 22 Konferencji Naukowo-Technicznej, Ciechocinek 5-7.10.2016, 61.

\section{MANAGEMENT OF EXPLOITATION IN TERMS OF LIFE CYCLE COSTS OF BUILT STRUCTURES}

\section{SUMMARY}

In the article the authors discuss preliminary information necessary to determine the scope and development direction for the optimization method concept of life cycle cost of selected buildings. The authors draw special attention to the close connection between decisions taken at the design stage and expenses incurred in the course of maintenance and use of building objects, present specifics of life cycle costs, discuss the components of costs and give the example of LCC analysis in this area.

Key words: life cycle cost - LCC, exploitation, building 